\title{
\#QuédateEnCasa, because it's not just flu: The impact of cognitive authorities' communication on human behaviour during the pandemics
}

\section{KRISTÍNA BÖHMER}

Institute of European Studies and International Relations, Faculty of Social and Economic Sciences, Comenius University in Bratislava, Mlynské luhy 4, 82105 Bratislava, Slovakia, grebacova2@uniba.sk

\begin{abstract}
The main objective of this study is to point out the importance of communication by cognitive authorities, in this case of political elites, during the health crisis. Their rhetoric can have an enormous impact on the behaviour of the general population. If these cognitive authorities recommend following the advice of health authorities, people are more likely to follow the advice. This can come out as a crucial factor in preventing the spread of the virus during any epidemics. A virus could be more predictable if human behaviour were predictable as well. Confirming the impact of cognitive authorities on the general public's behaviour during a health crisis might help us understand what needs to be done differently by those political elites if there will be any other health crisis in the future.
\end{abstract}

Keywords: cognitive authority, social media, health crisis, pandemics

\section{Introduction}

"Trust in our public health system which is perfect for this type of crisis," 1 said prime minister of Spain Pedro Sánchez after the confirmation of the first case of COVID-19 in mainland Spain.

"We are encouraging the population to scrupulously observe their health condition and restrict participation in the places with bigger concentration of people," said his Slovak counterpart, then-prime minister Peter Pellegrini ten days later, after the confirmation of the same disease in Slovakia.

The approach of the political authorities in Spain and Slovakia was different from the very beginning of the crisis, caused by the new coronavirus known as COVID-19. While Spanish authorities called for people to trust the healthcare system, Slovak authorities asked people to wear face masks or stay at home. Members of the Slovak government themselves, whether the previous government of Peter Pellegrini, or the one of his successor Igor Matovič, set an example for the Slovak population. The photograph after the appointment of the new government of Igor Matovič on 21 March 2020 will go down in history; all politicians in the photograph are wearing face masks. Obviously, several fac-

\footnotetext{
${ }^{1}$ Redacción. (2020). 'Sánchez pide "confianza” en el sistema sanitario tras el primer caso de coronavirus en Cataluña' Crónica Global. 25.2.2020. Available at: https://cronicaglobal.elespanol. $\mathrm{com} /$ politica/sanchez-pide-confianza-sistema-sanitario-casocoronavirus-cataluna_321734_102.html [Accessed:6-Apr-2020]

${ }^{2}$ Hajč́ková, D. (2020). 'Na Slovensku potvrdili prvý prípad koronavírusu, od pondelka sa zakážu lety do Talianska', SME. 6.3.2020. Available at: https://domov.sme.sk/c/22351714/na-slovensku-potvrdili-pripad-koronavirusu.html [Accessed: 3-Apr-2020]
}

tors have an impact on the spread of pandemics, and sometimes these factors differ from country to country. Nevertheless, one of the most powerful factors is the human factor. The virus needs a host and the host needs to be in contact with another potential host for the virus to spread. It is possible to stop, or at least slow down, the virus by measures which must be followed by humans.

Somebody has to communicate these measures to the public. To persuade people, it must be someone trustworthy and credible. In the words of Patrick Wilson, "somebody who knows something we don't know" (Wilson, 1983, p. 10). This is how Wilson defined cognitive authority, and political elites can be potential cognitive authorities. Regarding the spread of COVID-19, cognitive authorities in different countries communicated the pandemics differently. While Spanish political elites started to perceive the situation as being serious when 1,204 Spaniards were infected and 29 were dead, their Slovak counterparts did that from the very beginning, after the confirmation of the first case of COVID-19 in Slovakia. Following their cognitive authorities' communication, the population of these two countries behaved differently. While Spaniards continued in their daily routines like before, Slovaks quarantined themselves voluntarily.

Spain is one of the worst hit countries, and in regard to the numbers of infections the most hit country in Europe. That makes Spain a perfect contrasting example with Slovakia, the former Soviet bloc country with the population used to follow the orders, where the restrictions were taken early. This paper argues that communication of the cognitive authorities, in this case, the 
prime ministers, is an important factor influencing the spread of virus. To compare their communication, I analysed the statements of the chosen cognitive authorities published on the social media platforms which are important tools for spreading information today. I evaluated the posts of prime ministers of Spain and Slovakia according to their approach to the virus (whether they encourage the public to be careful or to continue in their daily routines as before). Finally, I matched the evaluations of the posts with the numbers of confirmed cases of COVID-19 in their country. Is there a correlation between the cognitive authorities' communication and the spread of the virus? The research question is: Can cognitive authorities influence the spread of the virus during pandemics through influencing human behaviour?

\section{Theoretical background}

\subsection{Who is a cognitive authority?}

For many voters, what their favourite politician says must be true. We vote for our chosen politicians because we trust them enough to believe that what they say is valid. In Wilson's words, those politicians have become our cognitive authorities because "they know something we don't know" (Wilson, 1983, p. 10). "Some people know what they are talking about, others do not. Those who do are my cognitive authorities" (Wilson, 1983, p. 10). Based on Wilson's research, Rieh defined cognitive authority as "a kind of influence. Those who are cognitive authorities profoundly influence others' thoughts" (Rieh, 2010, p. 1340). Wilson highlighted that cognitive authority has something to do with credibility (Wilson, 1983, p. 15). Credibility is an important factor influencing the perception of newly gained information. Many researchers have studied credibility from different angles of view. For instance, according to O'Keefe, "credibility (or, more carefully expressed, perceived credibility) refers to the judgments made by a perceiver (e.g., a message recipient) concerning the believability of a communicator" (O’Keefe, 1990, (p. 130-131). Judgments of credibility are not objective because people decide what to believe and what not to believe. Rieh in his paper defined credibility "as people's assessment of whether the information is trustworthy based on their own expertise and knowledge" (Rieh, 2010, p. 1338).

Source credibility, which means the credibility of the person or the institution spreading information, hence the source, has been studied for decades. In their famous experiment published in 1951, Hovland and his team at Yale University focused on the perception of sources and the influence on the credibility of the communication. They presented an identical message to two groups, "one in which a communicator of a generally trustworthy character was used, and the other in which the communicator was generally regarded as untrust- worthy" (Hovland, Janis \& Kelley, 1953, p. 636). One of the topics was building a practicable atomic-powered submarine at that present time. While the high credibility source was Robert J. Oppenheimer, an American physicist credited as the father of the atomic bomb, the low credibility source was Pravda, the then-official newspaper of the Communist Party of the Soviet Union (Hovland, Janis \& Kelley, 1953, p. 637).

The results showed that "although the communications being judged were identical, there was a marked difference in the way the subjects responded to the high credibility and low credibility sources." Not in the case of information, because researchers did not notice a significant difference in the number of facts and information gathered from the text when attributed to the high credibility source or low credibility source. "Significant differences were obtained in the extent to which opinion on an issue was changed by the attribution of the material to different sources" (Hovland, Janis \& Kelley, 1953, p. 641-642).

Since Hovland's experiment, several scales have been developed for measuring source credibility. Metzger and Flanagin, when referring to those scales, highlighted those by McCroskey, Berlo et al., and Leathers. "McCroskey's scales assess five dimensions of source credibility (character, competence, sociability, extroversion, and composure), whereas the other scales include only three dimensions; Berla et al. measure safety (i. e., friendliness, trustworthiness), qualification (i. e., expertise), and dynamism; Leathers measures competence, trustworthiness, and dynamism" (Flanagin \& Metzger, 2000 , p. 299). When using any method of measuring trustworthiness, one of the crucial factors should be group membership.

Indeed, group membership can make people 'blind', and this highly influences people when deciding whom to trust. As a part of preservation, Goldman highlighted peer disagreement as an area of social epistemology which in a way refers to group membership, even though not entirely. As Goldman asked when determining who is our peer (somebody on the same intellectual level as ourselves), is it legitimate to rely on our previous knowledge, compare it with new evidence, and then decide whether we trust those people or not? "If one uses same- mindedness as a criterion of trustworthiness, doesn't one run the risk of consulting those who share the same biases, false theories, or bad company that plague one's own first-order belief set? Does this mean that one should set aside one's first-order beliefs in deciding who are reliable sources of further evidence and turn instead to high-order evidence about belief-forming methods and sources?" (Goldman, 2010, p. 11). This has proved essential when defining the role of cognitive authority in the process of determining whom to trust, and the impact of shared membership in a group with this particular cognitive authority. 
It is not only about the group membership itself, but also about one's established viewpoint, or one's advocated position. People tend to trust those whose opinions they share, and whom they believe is somewhat similar to them in their views on that particular issue. McKenzie linked the concept of cognitive authority with the positioning theory ${ }^{3}$ proposed by Rom Harré and Luk van Langenhove, according to which positioning is "the assignment of fluid parts or roles to speakers in the discursive construction of personal stories that make a person's actions intelligible and relatively determinate as social acts" (cited in McKenzie, 2003, p. 270). Later McKenzie used Potter's framework for analyzing everyday fact construction and linked it with positioning, and the building up or undermining the authority of information sources. In her research on pregnant women, she found out that her subjects tended to trust two different types of sources: "biomedical authoritative knowledge and knowledge that derives its authority through the lived experience of the information source" (McKenzie, 2003, p.271). This shows that when people don't have the opportunity to live through the experience, they tend to believe those who have already experienced it.

But as her research shows later, actual experience is not enough if the result does not follow one's previous information or view on that particular issue. McKenzie calls it interest management, when someone describes the source of information as biased, and hence, they have a reason why they do not consider the source trustworthy. The other important point is what one will do once one gathers the information. As Wathen and Burkell (McKenzie, 2003, p. 134) point out, it is possible that the received information, whether it is right or wrong, would be limited to learning, which means that a person will gather the knowledge, store it and maybe later recall it. But they also pointed out that "in many cases, however, there is a much larger impact. Information can be passed on to others, it can be used to make decisions, and it can affect attitudes and behaviors."

\subsection{Mass media vs. social media}

Cognitive authorities can share their opinions with the public via several channels. Previously, the option for spreading of information widely was mass media. Thanks to mass media, information was able to reach a wide population. Nowadays, the fame of mass media is overshadowed by several social media platforms. Mass media and social media are two different worlds; for instance, when studying the credibility of mass media, different reference objects can be examined. Schweiger

\footnotetext{
${ }^{3}$ McKenzie linked these two theories in her research about discursive strategies of information seekers on interviews with pregnant women expecting twins.
}

(2000) defined six levels of reference objects: presenter (receiver is confronted with them, for example, a presenter of TV news, author of political comment in a magazine, etc.), actor (their statements are quoted in the news, e.g. a statement of a prime minister regarding budget), editorial units (complete programs or single news items), media products (newspapers, TV or radio broadcasts, online news sites, etc.), subsystems of media types (for instance, quality papers versus tabloid press), media type (TV, radio, print) (Schweiger, 2000, p. 39-41).

In the case of the pandemic caused by the new coronavirus COVID-19, just as in other important cases for receivers of mass media content, journalists have been following statements by political elites at regular press conferences, which have been held every day (in Spain as well as in Slovakia) to inform them about the particular details of the pandemic. Journalists have also been following updates on new cases and deaths in statistics provided by the ministry of health of the particular country every day. Their information is published daily by several mass media. Many of these outlets have a pay wall and only subscribers have access to the stories published by those mass media. This is where social media enters the game.

Unlike mass media, social media is free to access, free to publish content, free to receive and consume. Create a profile and the user is ready to start browsing and scrolling, looking for people they want to follow and get to the information provided. For those who are authorities, or want to become authorities, social media is the easiest way to get the attention, and with the attention, either glory or hatred. Politicians know that. Karlström and Pettersson (2011) studied the social media activity of every member of Parliament in Sweden and concluded:

Reputation is for politicians what a product is for a company... Before social media there were fewer venues for politicians to cultivate their image and build their reputation, and most such channels were mediated by journalists and content providers. The introduction of social media in politics opens new venues for discussion and profiling, and these new venues serve as a more direct channel to voters (Karlström, \& Pettersson, 2011, p. 1).

Politicians started using internet communication for various reasons. As Tim Highfield pointed out in the book Social Media and Everyday Politics, politicians could use digital platforms for engaging with their voters and with issues, or also simply for broadcasting their statements, press releases or speeches (Highfield, 2016, p.123). To provide their statement and sometimes even pure opinion is much easier via their social media accounts because it is not edited by a journalist. In other 
words, the content published on social media by themselves or their teams is a pure statement without any corrections, interventions, or having been taken out of context by a journalist.

As well as general internet users, politicians can choose between different social media to create a profile and use it to interact with their electorate. They might consider one type of communication much more effective. Highfield, in his research focusing on the politicians actively using social media, pointed out that $\mathrm{Fa}$ cebook provides space for more extended comments than Twitter, which "may make it a better option for making politicians' contributions visible and encourage interactions and responses" (Highfield, 2016, p. 124). He also pointed out that "Facebook may be a stronger option for an engagement, and for monitoring this through centralized metrics around likes, shares and comments on a politician's or party's page" (Highfield, 2016, p. 126). Twitter, by comparison, may be used as a broadcast platform, where politicians might provide links and updates without engaging in interactions with others (Highfield, 2016, p. 125). On the other hand, "Twitter, meanwhile, offers advantage of quick and concise commentary and sharing information" (Highfield, 2016, p. 126).

When deciding which platform to use to engage with the electorate, politicians might also think about the popularity of the social media platform in their country, or even about their target group. Larsson and Kalsnes, when studying the social media activity of every member of Parliament in Sweden and Norway, found that even though a larger part of the Scandinavian population uses Facebook than Twitter, Scandinavian politicians are more active on the latter. That might indicate "potential online communicative mismatch between those electing and those elected" (Kalsnes \& Larsson, 2014, p. 663). According to Larrson and Kalsnes, Twitter is in Scandinavian countries linked to elite, urban, media-savvy groups. "If Scandinavian politicians wish to engage more clearly with everyday voters and regular citizens, outside of metropolitan power elites, they might be well served to look beyond Twitter for their social media activities" (Kalsnes \& Larsson, 2014, p. 663).

\subsection{Behaviour change during health crisis}

As mentioned before, politicians can use social media with different aims. Except for publishing their press releases or updates after important negotiations to show their merits and credits, they have endless possibilities to spread their opinions or appeals. That is exactly what they were doing during the latest COVID-19 pandemic. They appealed to the general public to behave in a manner which is preferred in the crisis. As we know from the theory of cognitive authorities, the impact of politi- cal elites might be enormous on the behaviour of the public, as people tend to follow the leads of those whom they trust, and the way the public behaves is crucial for the spread of the virus.

When Halstead studied parasitism from the perspective of human contribution, he underlined that "human behaviour is often the decisive determinant of emergence; further, a change in human behaviour can be the single most powerful defence our species has against the phenomenon of infectious disease emergence" (Halstead, 1996, p. 22). The virus cannot exist on its own; it needs a host, from which it needs to spread to another potential host. The modern era makes it easy for a virus to spread quickly throughout the whole world, thanks to numerous modes of transportation and travel, mass production and the export meat, vegetables, or fruit across continents.

We know how to fight against many known viruses. With AIDS, sexual behaviour needs to be changed. For cholera, water has to be either boiled or chlorinated. For yellow fever, we have a vaccine. For COVID-19 there are no established preventions. But since it is a coronavirus hand hygiene, sneezing in a tissue, and social distancing might help in beating the pandemic or at least slow it down. The question is: would people perform the hygiene steps and social distancing better if their cognitive authorities told them to? Is the spread of the pandemic of COVID-19 slower in countries where the political elites supported the public in a behaviour change from the beginning? How does the curve of coronavirus spread look like in Slovakia and Spain, two countries with different approaches by political elites?

\section{Methodological approach}

The research focused on two European countries, both of them struggling with COVID-19. The first was Spain, one of the hardest-hit European countries by COVID-19. At the time of writing this study, Spain had the biggest number of confirmed cases of COVID-19 in Europe and the second highest number in the world after the USA. Spain has the second greatest number of confirmed deaths caused by COVID-19 in Europe after Italy in absolute numbers, but the highest mortality rate. On the other hand, Slovakia is still one of the least hit countries in the world, with confirmed cases counted in the hundreds. Although the results are extremely different, the measures taken by governments of both countries are now very similar. The difference is in the time of action. While Slovakia adopted strict measures after confirming the first case of COVID-19, Spain did so after confirming 1,204 infections and 29 deaths. But it's not only about the measures. It's about communication, which was highlighted also by Halstead in his study about the human factor in virus spreading. 
After choosing the countries, I identified political elites who appeared to be potential cognitive authorities regarding COVID-19. They needed to be political elites representing parties with a wide electorate in their countries to secure their impact on the general public; they had to be faces of the struggle against the pandemic, which means they had to be actively participating in negotiations as well as in communication with the general public via speeches or press conferences, they had to be quoted by mainstream mass media in their countries and they had to be active on social media to get in touch with the public. Based on these presumptions, I identified the prime ministers of both countries as cognitive authorities eligible for this research. In Spain, the prime minister is Pedro Sánchez. In Slovakia, the situation is more complicated because of the change of cabinet during the studied period. At the beginning of the pandemic in Slovakia, the prime minister was Peter Pellegrini. On 21 March 2020, a new government was appointed, and since then the prime minister has been Igor Matovič. I realize it is not proven that these political elites are cognitive authorities. I assume they are because of their wide electorate, but for future reference this might be investigated properly.

The period in this study was different for both countries since the outbreak of the epidemic was not parallel. I started collecting the data on the day of the first confirmed case in both countries. For Spain, the beginning of the research starts on 25 February 2020, while for Slovakia, it starts on 6 March 2020. I collected data for a period of six weeks, because in Spain it took six weeks for the virus to get to the peak and to stabilize. To be precise, the peak in Spain was on 31 March, exactly five weeks after confirming the first case, and the latter week was a stabilizing phase.

Because of the limits of this research, it was not possible to analyse all mainstream media to find the quotes by the studied cognitive authorities. On the other hand, I don't consider it crucial for research of this kind. Firstly, the majority of media use the same quotes that the cognitive authorities said during daily updates on the press conferences. It would be too time-consuming for little effect. Considering only online media, which would be the easiest way, many of these platforms are paid, which means their content is not open to all internet users. Paying for content does not apply to social media, which is a perfect choice for studying the impact of cognitive authorities on the behaviour of the public.

For this study, the best choices were Facebook and Twitter. I decided to study both of them, because Spanish politicians are more active on Twitter, while Slovak politicians use Facebook more often to interact with their electorate. For instance, Slovak prime minister Igor Matovič has not been active on Twitter since 2016. The former prime minister, Peter Pellegrini, has an active Twitter account, but his updates are very scarce and always in English, which not all Slovaks speak. When Larrson and Kalsnes were studying the social media activity of every member of Parliament in Sweden and Norway, they pointed out that fan pages are more reliable sources for politicians on Facebook than their personal accounts. "Given the specialised features made available by the Pages feature (through the Facebook Insights service), our argument was that this delimination would give us some indication of the degree of professionalisation evident among Swedish and Norwegian politicians when dealing with social media" (Kalsnes \& Larsson, 2014, p. 655). In the case of Peter Pellegrini, I studied his fan page, but in the case of Igor Matovič this was not possible since he uses his personal account as his official one. Although Pedro Sánchez is active on Facebook, I decided to study Twitter because of its greater popularity among the Spanish population. Moreover, all his tweets are also published on Facebook, but he publishes more on Twitter because of retweeting tweets of other Spanish politicians who are not active on Facebook. This is the case for Spanish health minister Salvador Illa, who is also a crucial figure in the communication to the public about the COVID-19 crisis, and his retweets are important on the prime minister's Twitter wall.

There are differences between these social media platforms. For instance, the posts on Facebook are much longer and the followers can interact deeply. That is not easy on Twitter, where posts are limited to 280 signs. On the other hand, Twitter users who want to publish a tweet longer than 280 signs can do that in a so-called 'thread', meaning they separate the tweet into more comments. During the period of this study, the Spanish prime minister used this option several times. That is why I consider the difference between those two social media platforms a lesser problem than the scarcity of posts on either one of the social media platforms by either of the Spanish or Slovak chosen cognitive authorities.

After choosing the countries, period of time, cognitive authorities, and platforms through which these cognitive authorities spread their insights, I paired all cognitive authorities' posts on social media to the date when they were published. I evaluated the statuses on a scale from -1 to 1 . The posts which encouraged the public to be careful - for example, about wearing face masks, social distancing, or home office - were marked with 1 . The posts about topics different than COVID- $19^{4}$ were marked with 0 . The posts which were neutral which means they did not encourage to comply

\footnotetext{
${ }^{4}$ I decided to include Spanish PM's tweets about the manifestation on the International Women Day even though the topic was different because those tweets encouraged the public to continue in their daily routine without taking measures to protect themselves against COVID-19.
} 
with the measurements, or even encouraged them to continue in their daily routine as before, were marked with -1 .

Then, I prepared a graph showing the increase of identified cases of COVID-19 in Slovakia and Spain. For Spain, I used numbers published by the Health Ministry of Spain on their official website 5 . For Slovakia, I used numbers published by the government on a new website created for information about COVID-196. At first, I matched the evaluations of the prime ministers' posts on social media platforms with the numbers of confirmed cases of COVID-19 in their countries. On this graph, the time the prime ministers reacted to the epidemics is visible, and how long it took them to take measures for combating the virus. If shifting the evaluations of prime ministers' communication within two weeks (the approximate incubation period), you can see what impact the cognitive authorities' communication had on the public ${ }^{7}$.

I finish it with a textual analysis of all the posts published by the cognitive authorities (Facebook in the case of Slovak cognitive authorities and Twitter in the case of Spanish cognitive authorities). Using the online software Online-Utility.org ${ }^{8}$, which provides utilities for online operating systems, I selected the most often used words in the cognitive authorities' posts. I counted how many times they mentioned covid19, COVID, coronavirus, or virus. Then I tried to find out what other topics - based on words used - dominated in their communication during the period in which the research was conducted. In the case of Slovak cognitive authorities, I had to group words in one group because of several different grammatical versions of the words. For instance, based on whether the word is a subject, an object, etc., in Slovak, you might use "koronavírusom, koronavírusu, koronavírus, koronavíruse," but it is still the same word - coronavirus. Second, I also grouped words with and without hashtags. This textual analysis showed how frequently the cognitive authorities communicated the pandemics, how often they talked about the safety measures taken, etc.

\section{Results}

\subsection{Spain}

On the day when the first case of COVID-19 was confirmed in mainland Spain, Spanish prime minister Pedro Sánchez tweeted:

\footnotetext{
${ }^{5}$ https://www.mscbs.gob.es/profesionales/saludPublica/ccayes/ alertasActual/nCov-China/situacionActual.htm

${ }^{6}$ https://covid-19.nczisk.sk/sk/

${ }^{7}$ Because of the incubation period, we can see the results of the communication within approximately two weeks.

${ }^{8}$ Available here: https://www.online-utility.org/
}

Sánchez, Pedro. (sanchezcastejon). "Today, the interministerial reunion about the coronavirus. This afternoon the health minister is going to meet with CCAA [Autonomous communities] to strengthen the awareness and measures to early detection, following the EU and WHO protocols. Full confidence in SNS [Public health care system] and its professionals." 25 Feb 2020, 1:32 PM. Tweet.

And then, for the next seven days, he did not mention the epidemic at all, even though the numbers of confirmed cases were rising. His tweets for those seven days were about the negotiations with Catalonia, upcoming elections in Basque country, the day of Andalusia, the day of the Balearian islands, and mainly about gender-based violence. International Women's Day was approaching, and the socialist government of Pedro Sánchez and his party PSOE identifies itself as a "feminist government." On the eighth day, he tweeted condolences to the families of the first victims of COVID-19, with the reassurance that the country has a "great health care system and excellent professionals" (Sánchez, Pedro. (sanchezcastejon). 4 Mar 2020, 8:26 PM. Tweet.) That was on 4 March. Four days later, on International Women Day, he retweeted a tweet of his party PSOE: "We went to the streets! Because equality is freedom, and freedom is democracy. PSOE will always fight with women!" (Sánchez, Pedro. (sanchezcastejon). 8 Mar 2020. Tweet.). The observations in several Spanish cities, among them Madrid with 120,000 people marching in the streets, took place on the twelfth day after confirming the first case of COVID-19 in mainland Spain.

After a couple of more reassuring tweets, the Spanish prime minister tweeted his first tweet asking the public for cooperation and following the rules set up by the health experts on the fourteenth day after confirming the first case of COVID-19 in mainland Spain. He tweeted:

Sánchez, Pedro. (sanchezcastejon). "Everybody can help to overcome the coronavirus crisis by following the recommendations of the experts. If we do what they say, we can protect our health, the health of our families and our fellow Spaniards. Those will be tough weeks, but together we can overcome it if everybody plays their role." 10 Mar 2020, 10:21 PM. Tweet.

He published this tweet on the day when there were 1,622 confirmed cases and 35 deaths in Spain. Three days later, on 13 March, he announced that "tomorrow we will declare the state of emergency," which was followed by the confinement of the majority of the Spanish population (Sánchez, Pedro. (sanchezcastejon). 13 Mar 2020, 4:18 PM. Tweet.). The change in Pedro Sánchez's rhetoric and communication towards the public is 
visible in Appendix A with his selected tweets. With the incubation period of approximately two weeks, Spain registered the peak of daily rises of new cases of COVID-19 on 31 March, exactly thirty-five days after the prime minister's first tweet asking for the cooperation of the general public.

In Figure 1 we can see how with the increase of the cases of COVID-19 in Spain the prime minister's activity on social media regarding COVID-19 has risen. The peak in the number of tweets about COVID-19 was on the day when Spain registered 4,209 cases of the disease. But, in the beginning, he did not communicate very much about the health crisis through social media. Even if he did, it was more or less praise of the Spanish health care system and health professionals. When shifting the number of cases within two weeks of the incubation period after the change of communication of the prime minister, it seems that the change in his communication had come too late. The exponential curve of COVID-19 cases was unstoppable at that phase.

Table 1: Milestones selected from tweets about COVID-19 on Spanish prime minister Pedro Sánchez’s Twitter wall (tweets as well as retweets).

\footnotetext{
A "Full confidence in the health care system"

B First death: "Our healthcare system is excellent."

C "We went to the streets." International Women Day

D The first tweet about following experts' recommendations

E Tomorrow declaration of the state of emergency

F "Stay at home to save lives."

G "Staying at home is an act of patriotism."

H Asking the Congress for extending the state of emergency

I Praise of health staff
}

During the period in which the research was conducted, Spanish prime minister Pedro Sánchez published 140 tweets. In all of them, he mentioned covid, covid-19, coronavirus, or virus, seventy times, in that he mentioned these exact words seventy times, but that does not necessarily mean that the rest of the tweets were not about the same topic. As I said earlier, on the day of the first case confirmed in Spain, he published one tweet about the pandemics, and the next seven days he did not communicate it at all. When he started communicating the topic after those seven days, he highlighted the impressiveness of the Spanish health care system and health professionals twice. During the period in which the research was conducted, he mentioned the word "measure/measures" seventeen times, but he never mentioned "the face mask/masks." However, he used the hashtag \# estevirusloparamosunidos which means "we will fight this virus together." Since his government identifies itself as a feminist government, he tweeted quite frequently about the gender violence.

Table 2: Words used most frequently by the Spanish prime minister Pedro Sánchez in his tweets during the period in which the research was being conducted

$\begin{array}{llc}\text { Keyphrase } & \text { Phrases } & \text { Occurrences } \\ \text { Coronavirus } & \begin{array}{l}\text { \#coronavirus, \#covid19, \#covid2019, } \\ \text { \#covid_19, coronavirus, covid, virus }\end{array} & 70 \\ \begin{array}{l}\text { We will fight this virus } \\ \text { together }\end{array} & \text { \#estevirusloparamosunidos } \\ \text { Measures } & \text { medida, medidas } & 29 \\ \text { State of alarm } & \begin{array}{l}\text { estado de alarma } \\ \text { (Gender) Violence }\end{array} & \begin{array}{l}\text { \#violenciamachista, } \\ \text { \#violenciadegénero, violencia }\end{array} \\ & \end{array}$

Tweets about COVID-19 by Pedro Sánchez Confirmed cases of COVID-19

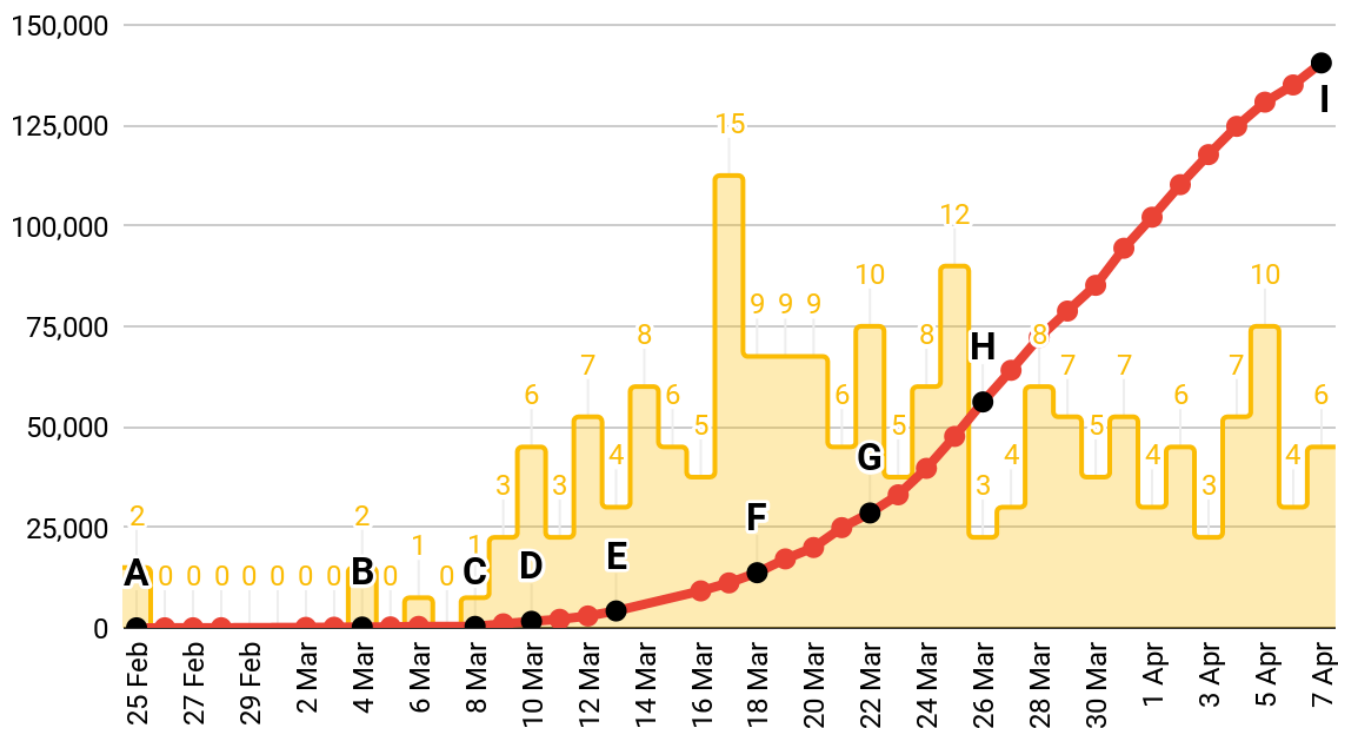

Figure 1: Increase of the cases of COVID-19 in Spain matched with the number of Tweets about COVID-19 on Spanish prime minister Pedro Sánchez's Twitter wall (Tweets as well as Retweets). 


\subsection{Slovakia}

Slovak then-prime minister Peter Pellegrini asked in a Facebook status for the cooperation and responsibility of the general public on the same day the first case of COVID-19 was confirmed in Slovakia. That day, 6 February, he posted four Facebook statuses. The first status was information about the coronavirus case in Slovakia; the second one was a video with instructions about the prevention; the third status was a video from his press conference about COVID-19. The last status of that day summarized several measures and recommendations, for instance, a ban on visits to hospitals or social homes, the cancellation of flights to and from Italy, and a recommendation for voluntary quarantine. These statuses were followed almost every day by more and more recommendations, and also reports on measures taken to slow down the spread of the virus. On the eighth day after the confirmation of the first case of COVID-19 in Slovakia, on 14 March, Peter Pellegrini, along with other Slovak political elites, started to wear face masks. That might be defined as an act of demonstrating how to behave during the health crisis. That day, he published on Facebook his photo wearing a face mask with the hashtag "a face mask is not a shame."

In comparison with the exponential curve of COVID-19 cases in Spain, the curve in Slovakia after six weeks from the first confirmed case is still linear. Of course, this might change with the increasing number of tests, but for now, the behaviour of the public, following the example of the prime minister, appears to have changed during the crisis and people follow recommendations of the health experts as communicated by the prime minister. In Figure 2, Peter Pellegrini as then-prime minister of Slovakia was highly active on social media since the very beginning of the health crisis in Slovakia. These data show that Peter Pellegrini was more active on social media regarding COVID-19 than his successor Igor Matovič.

After fifteen days since the first confirmed case of COVID-19 in Slovakia, the government changed. Igor Matovič became the new prime minister of Slovakia. Although his social media communication about the health crisis is basically the same - asking the population for cooperation and following the recommendations - his way of saying it is extremely different. As mentioned earlier in the section on methodologies, even though Igor Matovič has a fan page on Facebook, he is not active there. Instead, he is very active on his personal account. His communication is less straightforward and more difficult to analyse than the communication of Peter Pellegrini, who spoke very directly about the disease, measures, and recommendations. In the case of Igor Matovič, many posts were somewhere between personal and official, and many of them were either an attack on the former government or his current colleagues, or complaints about how difficult it is to manage the situation. The difference between the rhetoric of Peter Pellegrini and Igor Matovič is visible in Appendix B where selected statuses of both of the prime ministers are highlighted.

Because of this, it is sometimes difficult to distinguish between personal statuses, and official statuses. For instance, when communicating new measures, it is clearly official, but when writing about meeting a Roma

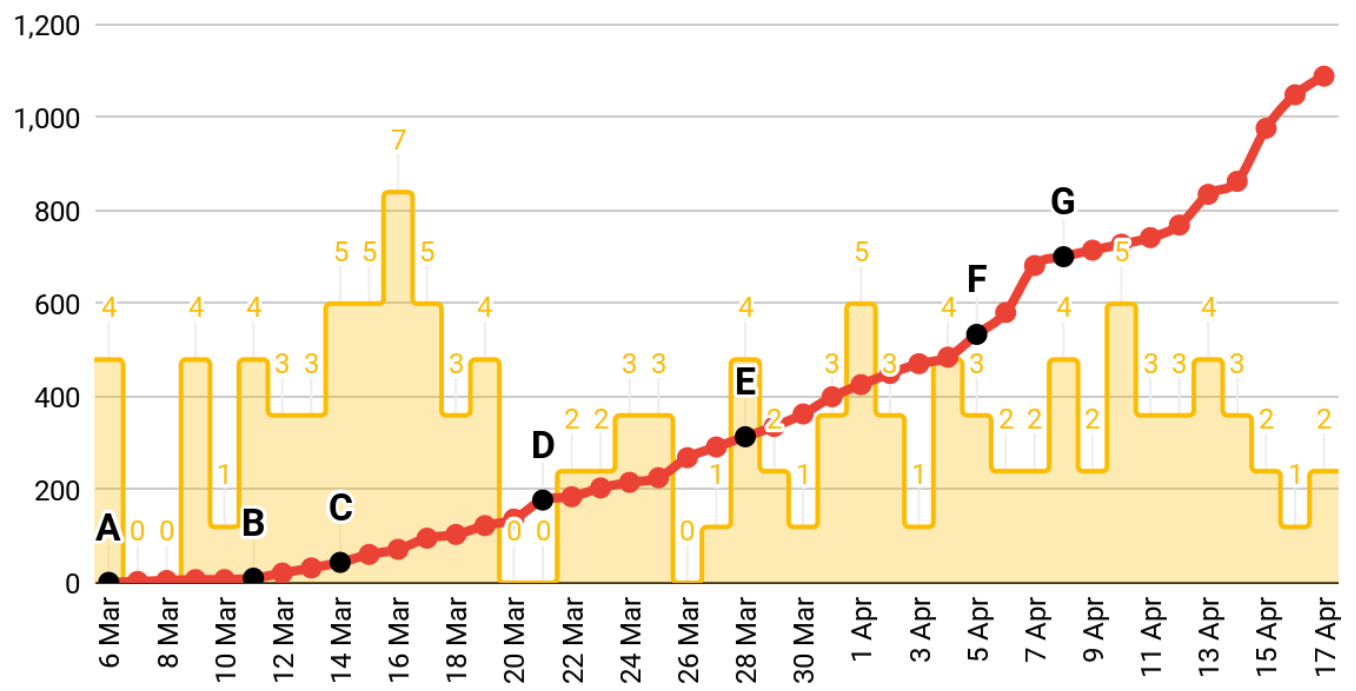

Figure 2: Increase of the cases of COVID-19 in Slovakia matched with the number of Facebook posts about COVID-19 on Slovak prime ministers Peter Pellegrini and since 21 March Igor Matovič on their Facebook wall. 
girl a couple of years ago, who used to live in the village which is quarantined now because of COVID-19, it is not clear whether it is a personal or official status, since the rhetoric and way how he expresses himself, is the same as in the cases of official information. For this reason, I decided to count all the statuses in which COVID- 19 was mentioned.

Table 3: Milestones selected from Facebook posts about COVID-19 on Slovak prime ministers Peter Pellegrini and since 21 March Igor Matovič on their Facebook wall.

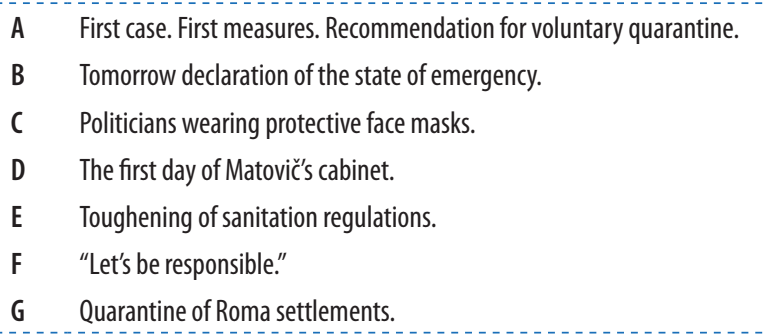

During the period in which the research was being conducted, Peter Pellegrini was the prime minister of the Slovak Republic for fifteen days. During these fifteen days, he published fifty-seven posts on Facebook, in which he mentioned "covid, covid19, coronavirus, or virus," sixty-two times. Besides that, the word "press conference" was mentioned fourteen times, as he used Facebook for publishing videos from his press conferences. He mentioned the "measures" fourteen times and presented the face masks as a necessity. He also used a hashtag \#ruskoniejehanba (A face mask is not a shame) once. Besides the topic of pandemics, he wrote posts about him leaving the office. Igor Matovic, from the time of becoming the prime minister of the Slovak Republic until the end of the period during which the research was being conducted, published ninetyeight posts on Facebook in which he mentioned the words "covid, covid19, coronavirus, or virus," twentyfour times. Many of his Facebook posts were personal since he uses the account not as a fan page, but it is his personal account. He mentioned "measures" seventeen times, and he also communicated the necessity of face masks. Communicating the safety measures by cognitive authorities is an important part of educating the public about how to stay safe and healthy. Besides the topic of the pandemics itself, he posted about Roma settlements even though he touched the topic of pandemics because his posts were about testing the inhabitants of Roma settlements or spreading the virus there. $\mathrm{He}$ was criticized by human rights activists for that.
Table 4: Words used most frequently by the Slovak prime minister Peter Pellegrini in his Facebook posts during the period in which the research was being conducted (and the period in which he was the prime minister).

$\begin{array}{llc}\text { Keyphrase } & \text { Phrases } & \text { Occurrences } \\ \text { Coronavirus } & \text { \#koronavirus, covid, covid 19, } & 62 \\ & \begin{array}{l}\text { korona, koronavírus, koronavíruse, } \\ \text { koronavírusom, koronavírusu }\end{array} \\ \text { Measures } & \begin{array}{l}\text { opatrenia, opatreniach, opatrení } \\ \text { Press Conference }\end{array} & \begin{array}{l}\text { tlačovej konferencii, tlačová } \\ \text { konferencia, tlačovú konferenciu }\end{array} \\ \text { State of Alarm } & \text { núdzový stav } & 14\end{array}$

Table 5: Words used most frequently by the Slovak prime minister Igor Matovič in his Facebook posts during the period in which the research was being conducted (and the period in which he was the prime minister).

\begin{tabular}{|c|c|c|}
\hline Keyphrase & Phrases & Occurrences \\
\hline (Roma) Settlement & $\begin{array}{l}\text { osadami, osade, osadu, osady, } \\
\text { osadách, osád }\end{array}$ & 33 \\
\hline Coronavirus & $\begin{array}{l}\text { covid, covid 19, korona, koronavírus, } \\
\text { koronavírusu }\end{array}$ & 24 \\
\hline Measures & $\begin{array}{l}\text { opatrenia, opatreniami, opatrenie, } \\
\text { opatrení }\end{array}$ & 17 \\
\hline Quarantine & karanténe, karantény & 16 \\
\hline
\end{tabular}

\section{Discussion and future reference}

Observing the curve of daily rises of new COVID-19 cases in Spain and Slovakia in Figure 3, the difference is extreme. The Spanish curve is much more drastic than the Slovak curve. While both prime ministers were calling for the cooperation and responsible behaviour of the general public during the six week observation period, though in different ways of expressing themselves, the crisis caused by COVID-19 is less severe in Slovakia than in Spain. Spanish prime minister Pedro Sánchez started with celebrating the Spanish health care system, creating an image of an untouchable country where the epidemics did not stand a chance to spread. In Slovakia, on the other hand, the threat was communicated clearly. Both Slovak prime ministers warned the public about the danger which COVID-19 might bring. This paper shows that how cognitive authorities communicate the crisis has an enormous impact on how the general public behaves in times of crisis. Since the behaviour of the public is crucial to how a virus spreads, a change in the communication of cognitive authorities might change the spread of the virus by changing the behaviour of the population. 


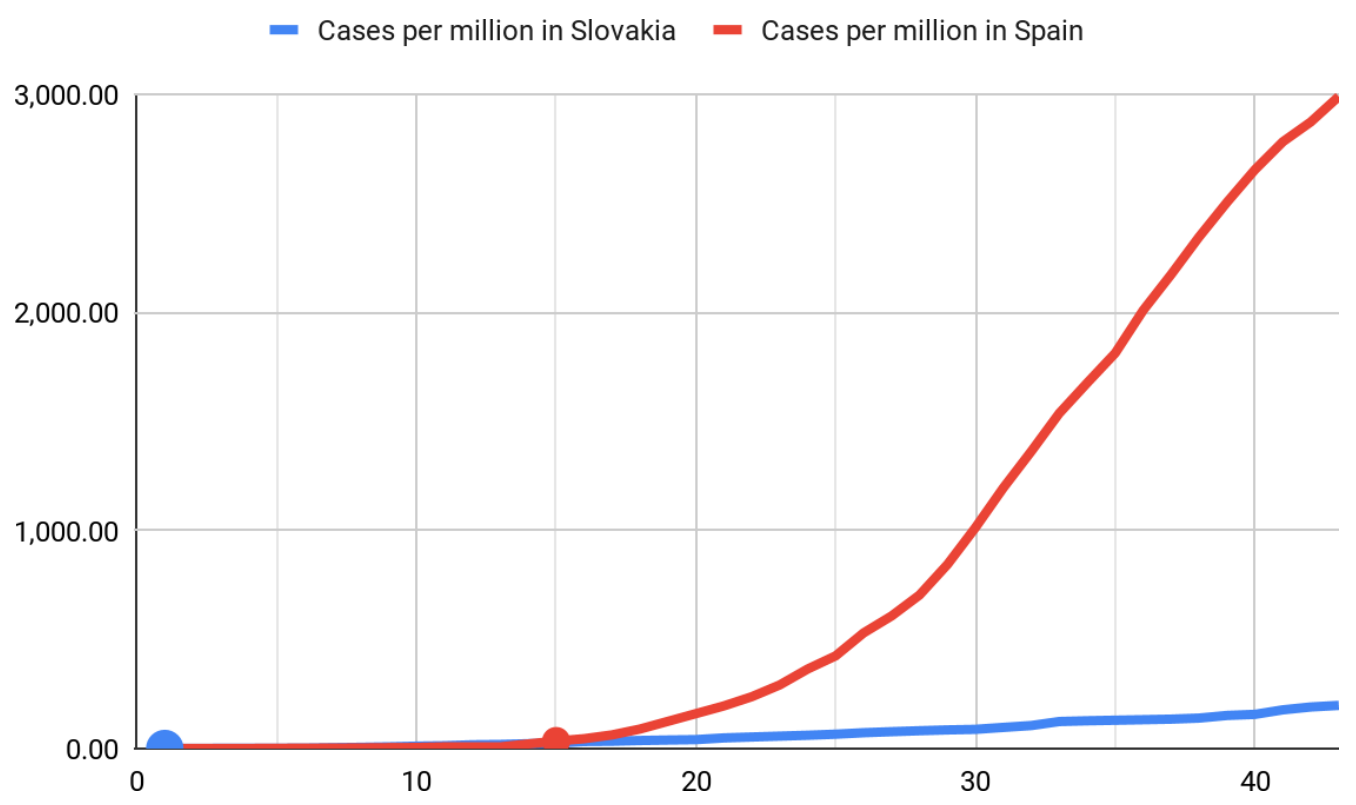

Figure 3: Comparison of the curve of COVID-19 cases in Spain and Slovakia.

I am well aware that the communication of cognitive authorities is not the only factor influencing the spread of epidemic even though as the results have shown, it is an important one. Because of the limitation of this study, I was not able to work with more variables. Several other factors have a considerable impact on pandemics. Sure, the difference is in taking official measurements. Since Slovakia took measurements sooner than Spain, the public basically did not have many opportunities where to go. The shops, theatres, cinemas, etc. were closed. Spanish public, on the contrary, was allowed to continue in their daily routines since the measures were not taken that soon. We might also assume that the Slovak population follows the rules because the rules are legally imposed since the official measures in Slovakia were taken early. It would mean that following the rules is not about cognitive but legal authority. This is only partially true. For instance, wearing protective masks was not legally imposed but the Slovak population started wearing them at the beginning of the crisis, just like the cognitive authorities. Spanish population did not wear face masks from the beginning of the crisis, and neither did their cognitive authorities.

Other variables are the cultural and sociological background of both countries, influenced also by historical background. Spaniards are much more sociable than Slovaks. Their daily life is based on interacting with other people and in close contact. This is partially based on the historical context. Slovaks as inhabitants of the former totality regime tend to isolate themselves and not trust anybody.
Sociodemographic factors might be considered as well. The density of the population might have a big impact on the spread of pandemics as well as the fact whether the majority population lives in cities or villages. The financial factor, which means how well off are the inhabitants, and whether their standard of living allows them to travel a lot. Quality of the public health system, education, and sanitation are crucial as well. This paper aims to be a simplified model of how the communication of cognitive authorities might influence the pandemics by influencing human behaviour.

Regarding the words used by the cognitive authorities in their posts published either on Twitter, or Facebook, the cardinal difference is in timing. While the Slovak cognitive authorities started using the words "covid, covid19, coronavirus, or virus," from the beginning of the epidemics in their country, their Spanish counterpart stayed quiet about the topic for the next seven days from the day when the first case of COVID-19 was confirmed in Spain. The other difference was in communicating the safety measures and the necessity of wearing a face mask. The Slovak prime ministers, both of them in the way of communication typical of them, talked about the measures which had been taken by the government and presented the necessity of wearing a face mask. The Spanish prime minister did not do that. In Table 6, we can see a number of posts published by the cognitive authorities, and how many times they used the words "covid, covid19, coronavirus, or virus." 
Table 6: Comparison of the number of posts published on selected social media platforms by Spanish and Slovak cognitive authorities and of how many times they mentioned COVID-19.

$\begin{array}{ccccc}\begin{array}{c}\text { Cognitive } \\ \text { authority }\end{array} & \begin{array}{c}\text { Number } \\ \text { of posts }\end{array} & \begin{array}{c}\text { Number } \\ \text { of characters } \\ \text { (including } \\ \text { spaces) }\end{array} & \begin{array}{c}\text { Number } \\ \text { of words }\end{array} & \begin{array}{c}\text { Coronavirus } \\ \text { mentions }\end{array} \\ \begin{array}{c}\text { Pedro } \\ \text { Sánchez }\end{array} & 140 & 37,199 & 5,481 & 70 \\ \begin{array}{c}\text { Peter } \\ \text { Pellegrini }\end{array} & 57 & 16,473 & 2,300 & 62 \\ \begin{array}{l}\text { Igor Matovič } \\ \text { Pat }\end{array} & 98 & 30,536 & 4,780 & 24 \\ \end{array}$

\section{Acknowledgements}

This paper was prepared as a part of doctoral research. No conflict of interest is assumed. Special thanks to Associate Professor Olga Gyárfášova, the director at the Institute of European Studies and International Relations at The Comenius University in Bratislava, and Professor Steven Saxonberg of the same institute, for their advice and guidance.

\section{References}

Flanagin, A. J. \& Metzger, M. J. (2000). Perceptions of Internet information credibility. Journal of Mass Communication Quarterly, 77(3), p. 515-540. https://doi.org/10.1177/ 107769900007700304

Fritch, J. W., \& Cromwell, R. L. (2001). Evaluating Internet resources: Identity, affiliation, and cognitive authority in a networked world. Journal of the American Society for Information Science and Technology, 52(6), p. 499-507. https://doi.org/10.1002/asi.1081

Goldman, A. I. (2010). Why social epistemology is the real epistemology. Available here: http://fas-philosophy.rutgers.edu/ Goldman/Why\%20Social\%20Epistemology\%20is\%20Real\%20 Epistemology.pdf. [Accessed: 10-Apr-2020]

Gunther, A. C. (1992). Biased press or biased public? Attitudes toward media coverage of social groups. Public Opinion Quarterly. 56, p. 147-167. https://doi.org/10.1086/269308

Halstead, S. B. (1996). Human factors in emerging infectious diseases. Eastern Mediterranean Health Journal, Vol. 2, No. 1, p. 21-29.

Highfield, T. (2016). Social Media and Everyday Politics. 1st ed. Cambridge: Polity.

Hogarth, R. M. (1987). Judgment and choice: The psychology of decision, 2nd ed. New York: John Wiley \& Sons.

Hovland, C. I., Janis, I. L. \& Kelley, J. J. (1953). Communication and persuasion. New Haven, CT: Yale University Press.

Kalsnes, B. \& Larsson, A. O. (2014). 'Of course we are on Facebook': Use and non-use of social media among Swedish and Norwegian politicians. European Journal of Communication. Vol. 29, p. 653-667. tps://doi.org/ $10.1177 / 0267323114531383$
Karlström, P. \& Pettersson, D. (2011): Reputation as a Product: Politicians in Social Media. Available here: http://www.diva-portal.org/smash/get/diva2:469599/ FULLTEXT01.pdf [Accessed: 15-Apr-2020]

Kohring, M. \& Matthes, J. (2007). Trust in news media: Development and validation of a multidimensional scale. Communication Research, 34(2), p. 231-252. https://doi.org/10.1177/0093650206298071

McKenzie, P.J. (2003). Justifying cognitive authority decisions: Discursive strategies of information seekers. Library quarterly, 73, 261-288. https://doi.org/10.1086/603418

Metzger, M. J., Flanagin, A. J., Eyal, K., Lemus, D. R. \& McCann, R. M. (2003). Credibility for the 21st century: integrating perspectives on source, message, and media credibility in the contemporary media environment. Communication Yearbook, 27, p. 293-335.

O'Keefe, D. J. (1990). Persuasion: Theory and Research. Newbury Park, CA: Sage.

Rieh, S. Y. (2002). Judgment of information quality and cognitive authority in the Web. Journal of the American Society for Information Science and Technology, 53(2), p. 145-161. https://doi.org/10.1002/asi.10017

Rieh, S. Y. \& Belkin, N. J. (1998). Understanding judgment of information quality and cognitive authority in the WWW. Journal of the American Society for Information Sciences. 35, p. 279-289.

Rieh, S. Y. \& Belkin, N. J. (2000). Interaction on the Web: Scholars' judgment of information quality and cognitive authority. In D.H. Kraft (Ed.), Proceedings of the 63rd ASIS Annual Meeting (pp. 25-33). Silver Spring, MD: American Society for Information Science.

Rousseau, D., Sitkin, S. B., Burt, R. S. \& Camerer, C. (1998). Not so different after all: A cross- discipline view of trust. Academy of Management Review, 23(3), p. 394-404. https://doi.org/10.5465/amr.1998.926617

Savolainen, R. (2007). Media credibility and cognitive authority. The case of seeking orienting information. Information research, 12(3), paper 319. Available here: https://eric.ed.gov/?id=EJ1104802. [Accessed: 6-Apr-2020]

Tsfati, Y. \& Cohen, J. (2013). Perceptions of media and media effects: The third-person effect, trust in media, and hostile media perception. The International Encyclopedia of Media Studies: Media Effects/Media Psychology, 1st ed. New York, Blackwell Publishing.

Vallone, R. P., Ross. L. \& Lepper, M. R. (1985). The hostile media phenomenon: Biased perception and perceptions of media bias in coverage of the Beirut massacre. Journal of Personality and Social Psychology, 49(3), p. 577-585. https://doi.org/10.1037/0022-3514.49.3.577

Schweiger, W. (2000). Media credibility - Experience or image? A survey on the credibility of the World Wide Web in Germany in comparison to other media. European Journal of Communication, 15, p. 37-59.

https://doi.org/10.1177/0267323100015001002

Wathen, C.N. \& Burkell, J. (2002). Believe it or not: factors influencing credibility on the Web. Journal of the American Society for Information Science and Technology, 53(2), p. 134-144. https://doi.org/10.1002/asi.10016

Wilson, P. (1983). Second-hand knowledge: An inquiry into cognitive authority. Westport, CT: Greenwood Press. 
Appendix A: Evaluation of daily tweets about COVID-19 on Spanish prime minister Pedro Sánchez's Twitter wall along with examples of the tweets (red is for negative sentiment, yellow for neutral sentiment, and green for positive sentiment).

\begin{tabular}{|c|c|c|}
\hline Date & $\begin{array}{l}\text { Evaluation of the } \\
\text { Tweets }\end{array}$ & Example of Tweets \\
\hline 25 Feb & -1 & $\begin{array}{l}\text { Sánchez, Pedro. (sanchezcastejon). "Today, the interministerial reunion about the coronavirus. This afternoon the health minister is going } \\
\text { to meet with CCAA [Autonomous communities] to strengthen the awareness and measures to early detection, following the EU and WHO } \\
\text { protocols. Full confidence in SNS [Public health care system] and its professionals" } 25 \text { Feb 2020, 1:32 PM. Tweet. }\end{array}$ \\
\hline 26 Feb & 0 & \\
\hline $27 \mathrm{Feb}$ & 0 & \\
\hline $28 \mathrm{Feb}$ & 0 & \\
\hline $29 \mathrm{Feb}$ & 0 & \\
\hline 1 Mar & 0 & \\
\hline 2 Mar & 0 & \\
\hline 3 Mar & 0 & \\
\hline $4 \mathrm{Mar}$ & -1 & $\begin{array}{l}\text { Sánchez, Pedro. (sanchezcastejon). "My condolences to the families of the coronavirus victims in the Basque Country and Valencia.I } \\
\text { am sending my solidarity to those who are infected. We have a great health care system and excellent professionals who work without } \\
\text { a break on early detection and treatment" } 4 \text { Mar 2020, 8:26 PM. Tweet. }\end{array}$ \\
\hline $5 \mathrm{Mar}$ & 0 & \\
\hline $6 \mathrm{Mar}$ & 0 & \\
\hline $7 \mathrm{Mar}$ & 0 & \\
\hline $8 \mathrm{Mar}$ & 0 & \\
\hline 9 Mar & -1 & $\begin{array}{l}\text { Sánchez, Pedro. (sanchezcastejon). "This morning, I participated in the Monitoring commission of coronavirus. My admiration for health } \\
\text { care professionals, mainly in the communities of Madrid, the Basque Country, and La Rioja, where they are giving a lot of effort. Their } \\
\text { work is a reflection of our solid national health care system." } 9 \text { Mar 2020, 9:51 AM. Tweet. }\end{array}$ \\
\hline $10 \mathrm{Mar}$ & 1 & $\begin{array}{l}\text { Sánchez, Pedro. (sanchezcastejon). "Everybody can help to overcome the coronavirus crisis by following the recommendations of the } \\
\text { experts. If we do what they say, we can protect our health, the health of our families and our fellow Spaniards. Those will be tough } \\
\text { weeks, but together we can overcome it if everybody plays their role." } 10 \text { Mar 2020, 10:21 PM. Tweet. }\end{array}$ \\
\hline $11 \mathrm{Mar}$ & 1 & \\
\hline $12 \mathrm{Mar}$ & 1 & $\begin{array}{l}\text { Sánchez, Pedro. (sanchezcastejon). "We are standing in front of an unprecedented health crisis. The Health Ministry has recommended } \\
\text { autonomous communities to take measures of social distancing.” } 12 \text { Mar 2020, 7:11 PM. Tweet. }\end{array}$ \\
\hline 13 Mar & 1 & $\begin{array}{l}\text { Sánchez, Pedro. (sanchezcastejon). "The victory depends on every citizen. Heroism is to wash your hands, stay at home and protect } \\
\text { yourselves to protect society. It will take weeks but we will destroy COVID-19 together with the social discipline when every one of us will } \\
\text { fulfil their tasks." } 13 \text { Mar 2020, 4:38 PM. Tweet. }\end{array}$ \\
\hline 14 Mar & 1 & \\
\hline $15 \mathrm{Mar}$ & 1 & \\
\hline $16 \mathrm{Mar}$ & 1 & \\
\hline 17 Mar & 1 & Economic injection for those in need \\
\hline $18 \mathrm{Mar}$ & 1 & $\begin{array}{l}\text { Sánchez, Pedro. (sanchezcastejon). "While there will be a vaccine for COVID-19, we are the vaccine. Everybody who stays at home and } \\
\text { follows the recommendations is helping to save lives and soften the curve. Every one of us is saving lives." } 18 \text { Mar 2020, 12:05 PM. Tweet. }\end{array}$ \\
\hline 19 Mar & 1 & \\
\hline 20 Mar & 1 & \\
\hline 21 Mar & 1 & Declaration of state of emergency \\
\hline $22 \mathrm{Mar}$ & 1 & $\begin{array}{l}\text { Sánchez, Pedro. (sanchezcastejon). "I ask you for responsibility and discipline. Irresponsibility costs us lives. Staying at home is today an } \\
\text { act of patriotism and solidarity." } 22 \text { Mar 2020, 5:31 PM. Tweet. }\end{array}$ \\
\hline $23 \mathrm{Mar}$ & 1 & \\
\hline $24 \mathrm{Mar}$ & 1 & \\
\hline 25 Mar & 1 & Intention to extend the state of emergency until April 11th \\
\hline 26 Mar & 1 & Congress accepted the extension of the state of emergency \\
\hline 27 Mar & 1 & \\
\hline $28 \mathrm{Mar}$ & 1 & Closing of all nonessential businesses \\
\hline 29 Mar & 1 & \\
\hline $30 \mathrm{Mar}$ & 1 & \\
\hline 31 Mar & 1 & \\
\hline
\end{tabular}


The impact of cognitive authorities' communication on human behaviour during the pandemics

\begin{tabular}{|c|c|c|}
\hline Date & $\begin{array}{l}\text { Evaluation of the } \\
\text { Tweets }\end{array}$ & Example of Tweets \\
\hline $1 \mathrm{Apr}$ & 1 & \\
\hline $2 \mathrm{Apr}$ & 1 & \\
\hline $3 \mathrm{Apr}$ & 1 & \\
\hline 4 Apr & 1 & Extension of state of emergency until April 25th \\
\hline $5 \mathrm{Apr}$ & 1 & \\
\hline $6 \mathrm{Apr}$ & 1 & \\
\hline $7 \mathrm{Apr}$ & 1 & $\begin{array}{l}\text { Sánchez, Pedro. (sanchezcastejon). "The health personnel is a cornerstone of the healthcare system which is crucial for us these days. The } \\
\text { misery which we are living in has to make us aware of the need to protect it and strengthen it. More public health means more collective } \\
\text { protection." } 7 \text { Apr 2020, 11:57 AM. Tweet. }\end{array}$ \\
\hline
\end{tabular}


Appendix B: Evaluation of daily Facebook posts about COVID-19 on Slovak prime ministers Peter Pellegrini and since 21 March Igor Matovič on their Facebook wall along with examples of the Facebook posts (red is for negative sentiment, yellow for neutral sentiment, and green for positive sentiment).

\begin{tabular}{|c|c|c|}
\hline Date & $\begin{array}{c}\text { Evaluation of the } \\
\text { statuses }\end{array}$ & Examples of statuses \\
\hline 6 Mar & 1 & $\begin{array}{l}\text { Pellegrini, Peter. "CORONAVIRUS IN SLOVAKIA - CENTRAL EMERGENCY COUNCIL HAS } \\
\text { TAKEN SEVERAL DECISIONS. This morning the first case of coronavirus infection was identified in Slovakia. The Central Emergency Council } \\
\text { has taken several decisions: 1. ban on visits to hospitals, social homes, and prisons with immediate effect. 2. starting on Monday, all } \\
\text { flights from and to Italy will be cancelled. 3. it is recommended to the Slovak citizens to quarantine themselves voluntarily and to not to } \\
\text { attend public events, shopping malls, or mass. At the same time, I want to calm down the public; there is no reason to panic. But in this } \\
\text { situation, for the interest of your own health, it is best to stay at home." } 6 \text { Mar 2020. Facebook. }\end{array}$ \\
\hline $7 \mathrm{Mar}$ & 0 & \\
\hline $8 \mathrm{Mar}$ & 0 & \\
\hline $9 \mathrm{Mar}$ & 1 & \\
\hline 10 Mar & 1 & \\
\hline 11 Mar & 1 & $\begin{array}{l}\text { Pellegrini, Peter. "DECLARATION OF STATE OF EMERGENCY IN SLOVAKIA. We don't } \\
\text { overestimate, either underestimate the situation. Based on the development of the situation regarding coronavirus, we decided on } \\
\text { today's government meeting to declare the state of emergency in Slovakia starting tomorrow at } 6 \text { am. Tomorrow the Central Emergency } \\
\text { Council will talk about two crucial issues: } 1 \text {. closing of all schools for } 14 \text { days, } 2 \text {. obligatory quarantine for all people coming from abroad. } \\
\text { I will inform you about the outcomes of the meeting." } 11 \text { Mar 2020. Facebook. }\end{array}$ \\
\hline $12 \mathrm{Mar}$ & 1 & Declaration of "extraordinary situation" + Closing bars, restaurants, skiing centres, or international airports. \\
\hline 13 Mar & 1 & \\
\hline $14 \mathrm{Mar}$ & 1 & Video from a press conference on which politicians were wearing protective face masks. \\
\hline 15 Mar & 1 & Declaration of state of emergency \\
\hline 16 Mar & 1 & \\
\hline 17 Mar & 1 & $\begin{array}{l}\text { Pellegrini, Peter. "LET'S BE DISCIPLINED. The discipline of all of us is today a crucial condition to be successful in the fight with coronavirus. } \\
\text { We need also recipients of social benefits to be disciplined these days, who have to copy with all the hygienic measures while getting } \\
\text { their social benefit at post offices. In other cases, the police are ready to act quickly." } 17 \text { mar } 2020 \text {. Facebook. }\end{array}$ \\
\hline $18 \mathrm{Mar}$ & 1 & \\
\hline 19 Mar & 1 & \\
\hline 20 Mar & 0 & The final day of Pellegrini's cabinet. \\
\hline $21 \mathrm{Mar}$ & 0 & The first day of Matovič's cabinet. \\
\hline $22 \mathrm{Mar}$ & 1 & \\
\hline 23 Mar & 1 & \\
\hline $24 \mathrm{Mar}$ & 1 & Matovič, Igor. "0:06 we are done. 40 measures for the fight with corona approved. Good morning, Slovakia." 24 Mar 2020. Facebook. \\
\hline 25 Mar & 1 & \\
\hline 26 Mar & 0 & \\
\hline 27 Mar & 1 & $\begin{array}{l}\text { Matovič, Igor. "Seeing the results. From day to day, we increased the number of tests from } 300 \text { to } 00 \text {... As a reward, I sat for a while } \\
\text { on the terrace at the Government to sunbathe a little bit ... Do the same, you too P. S.: Together we will beat this skunk" } 27 \text { Mar } 2020 . \\
\text { Facebook. }\end{array}$ \\
\hline $28 \mathrm{Mar}$ & 1 & $\begin{array}{l}\text { Matovič, Igor. "We have toughened the hygienic measures significantly. . . obligatory face masks, after entering a place it's obligatory to } \\
\text { disinfect your hands or gloves, } 2 \text { metres social distancing when standing in a line and one client for every } 25 \text { square metres of sales area } \\
\text { and we opened more services - gardening, gardening equipment, eye optics, } \\
\text { MOT and EC, computer and telephone service, lawyers, notaries, key services, garbage yards, textiles and haberdashery, sale and service } \\
\text { of bicycles, shops with building materials, installation and wiring materials, hardware - and materials for painting. }\end{array}$ \\
\hline $29 \mathrm{Mar}$ & 1 & \\
\hline $30 \mathrm{Mar}$ & 1 & \\
\hline $31 \mathrm{Mar}$ & 1 & \\
\hline $1 \mathrm{Apr}$ & 1 & \\
\hline $2 \mathrm{Apr}$ & 1 & $\begin{array}{l}\text { Matovič, Igor. "WE HAVE TO TOUGHEN THE MEASURES, EVEN MORE, SORRY FOR } \\
\text { THAT The measure, which we have already approved, helped us to become the third-best country in the world regarding the protection } \\
\text { against corona! That's why, if we won't slack off and we will toughen even more in our "blackout", which means switching off/slowing } \\
\text { down of Slovakia ... we will beat the skunk. Yes, it will cost more of our freedom, there will be tears and missing ... but we will save } \\
\text { hundreds or thousands of lives of our family members and friends." } 2 \text { Apr 2020. Facebook. }\end{array}$ \\
\hline
\end{tabular}




\begin{tabular}{|c|c|c|}
\hline Date & $\begin{array}{l}\text { Evaluation of the } \\
\text { statuses }\end{array}$ & Examples of statuses \\
\hline $3 \mathrm{Apr}$ & 1 & \\
\hline $4 \mathrm{Apr}$ & 1 & \\
\hline $5 \mathrm{Apr}$ & 1 & \\
\hline $6 \mathrm{Apr}$ & 1 & \\
\hline $7 \mathrm{Apr}$ & 1 & \\
\hline $8 \mathrm{Apr}$ & 1 & $\begin{array}{l}\text { Matovič, Igor. "The situation is grave, please, don't be a fool! ... That is the heading of today's press conference at 15:30. I believe that } \\
\text { after publishing the information, the repeated delirium of our coalition partners about opening the shops or schools right after Easter } \\
\text { will stop along with simplifying the disease COVID-19 as the flu. I believe that they will understand how extremely irresponsible they } \\
\text { are if they devalue the restrictions during the Easter holiday with their thoughtless speech and distancing from the valid government } \\
\text { resolution. This is not a playground, we are at war with an extremely dangerous enemy and any demoralisation of the team and attacks } \\
\text { on your own people are in the interest of evil, which is standing opposite to us." } 8 \text { Apr 2020. Facebook. }\end{array}$ \\
\hline $9 \mathrm{Apr}$ & 1 & \\
\hline $10 \mathrm{Apr}$ & 1 & \\
\hline $11 \mathrm{Apr}$ & 1 & $\begin{array}{l}\text { Matovič, Igor. "Early lifting of restrictive measures could lead to "deadly resurrection" of infections, the director of WHO doctor Tedros } \\
\text { Adhanom Ghebreyesus warned. According to him, the countries should be cautious regarding the lifting of measures, although several of } \\
\text { them are fighting with economic impacts of pandemics." } 11 \text { Apr 2020. Facebook. }\end{array}$ \\
\hline $12 \mathrm{Apr}$ & 1 & \\
\hline $13 \mathrm{Apr}$ & 1 & \\
\hline $14 \mathrm{Apr}$ & 1 & $\begin{array}{l}\text { Matovič, Igor. "I feel like a beaten dog. In the last week, even the last goof "hit me” just because I am repeating bŕŕr ... the [Roma] } \\
\text { settlements might explode, so we shouldn't rush into lifting the measures. Today we know that it was not just my bad foreboding and } \\
\text { I was, unfortunately, right about the settlements. So far } 16 \text { settlements are positive, and there are } 900 \text { more to test. A fire is burning, } \\
\text { which extension we can not measure. People of God, please, be extremely careful and do not slack off in your responsibility, keeping } \\
\text { the hygienic measures, minimising contacts and social distancing from people you love. I know that I am not a messenger of good news } \\
\text { and today those are in, who say what people want to hear. I will not do that, sorry. I promised you to tell the truth and I consider it even } \\
\text { more important in today's situation. By far we haven't jumped over it, we have to endure and we will make it even though it will be very } \\
\text { difficult." } 14 \text { Apr 2020. Facebook. }\end{array}$ \\
\hline $15 \mathrm{Apr}$ & 1 & \\
\hline $16 \mathrm{Apr}$ & 1 & \\
\hline $17 \mathrm{Apr}$ & 1 & \\
\hline
\end{tabular}

